НАУКОВИЙ ВІСНИК (1)

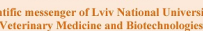

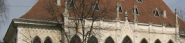
11) InImin

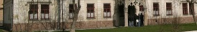
Том 21 № 92 2019

\section{Науковий вісник Дьвівського націонадьного університету} ветеринарної медицини та біотехнологій імені С.3. Гжицького. Серія: Харчові технології

\author{
Scientific Messenger of Lviv National University \\ of Veterinary Medicine and Biotechnologies. \\ Series: Food Technologies
}

ISSN 2519-268X print

https://nvlvet.com.ua/index.php/food

\title{
Technological Methods of Forming Thin Semiconductor Layers. Part 2
}

\author{
B. Tsizh ${ }^{1,2}$, Z. Dziamski ${ }^{1}$ \\ ${ }^{1}$ Kazimierz Wielki University in Bydgoszcz, Bydgoszcz, Poland \\ ${ }^{2}$ Stepan Gzhytskyi National University of Veterinary Medicine and Biotechnologies Lviv, Ukraine
}

\section{Article info}

Received 02.09.2019

Received in revised form 01.10 .2019

Accepted 02.10.2019

Kazimierz Wielki University in Bydgoszcz, 30 Chodkiewicza, Bydgoszcz, 85-064, Poland.

Stepan Gzhytskyi National University of Veterinary Medicine and Biotechnologies Lviv, Pekarska Str., 50, Lviv, 79010, Ukraine. Tel. + 38-032-239-26-35 E-mail:tsizhb@ukr.net
Tsizh, B., \& Dziamski, Z. (2019). Technological Methods of Forming Thin Semiconductor Layers. Part 2. Scientific Messenger of Lviv National University of Veterinary Medicine and Biotechnologies. Series: Food Technologies, 21(92), 3-7. doi: 10.32718/nvlvet-f9201

Features and basic technological methods of formation of thin layers of semiconductor materials in a vacuum with the method of thermal spraying in a quasi-closed volume are analyzed. The disadvantages of thermal spraying of thin films of multicomponent semiconductor compounds in an open vacuum are indicated. The designs of special collapsible evaporator chambers for thermo-vacuum sputtering in a quasiclosed volume containing the raw material and substrate in quasi-isolated conditions are presented. They allow to create and manage the necessary temperature corrections between the evaporator, lining, walls and other structural elements. The designs of special collapsible evaporator chambers for thermo-vacuum sputtering in a quasi-closed volume containing the raw material and substrate in quasi-isolated conditions are presented. They allow to create and manage the necessary temperature corrections between the evaporator, lining, walls and other structural elements. It is shown that the spatial temperature distribution in the discussed constructs provides the evaporation (sublimation) of the source material, the reflection of vapor from the heated walls, the intensive exchange interaction between the gas phase and the condensation surfaces and the prevailing condensation on the substrate surface, which contributes to the diffusion mechanism of the transfer of matter and to the thermodynamically balanced growth process for films. It is shown that for all modifications, to a greater or lesser extent, the conditions for the isolation of the localized volume and the equilibrium of the condensation process are fulfilled by creating the necessary temperature gradient. It is indicated that it is problematic to use such structures for mass production due to their complexity and technological features. That is why the method of thermal spraying of thin films in the quasiclosed volume is most often used in the production of epitaxial monocrystalline layers for scientific research and experimental development, and for industrial production it is very effective to develop methods for obtaining thin films, which from one hand combine universality of thermal spraying in opened vacuum and from another hand allow to bring the processes of evaporation (sublimation) and condensation closer to thermodynamic equilibrium, for example, various types of "hot walls". It is noted that the analyzed methods or their modifications are these necessary methods of creating thin-film semiconductor structures with predetermined properties.

Key words: thin films, semiconductors, technological methods of obtaining, condensation in a vacuum, thermal spraying, quasi-closed volume.

\section{Технологічні способи формування тонких напівпровідникових шарів. Частина 2}

\author{
Б. Ціж ${ }^{1,2}$, 3. Дзямскі ${ }^{1}$
}

${ }^{1}$ Kazimierz Wielki University in Bydgoszcz, Bydgoszcz, Poland

${ }^{2}$ Львівський національний університет ветеринарної медиции та біотехнологій імені С.3. Гжицького, м. Львів, Украӥна

Проаналізовано особливості та основні технологічні способи формування тонких шарів напівпровідникових матеріалів у вакуумі методом термічного напилення в квазізамкненому об 'ємі. Вказано недоліки термічного напилення тонких плівок у відкритому вакуумі для багатокомпонентних напівпровідникових сполук. Представлено конструкції спеціальних розбірних випарних камер для термовакуумного напилення у квазізамкненому об'ємі, які містять вихідний матеріал та підкладку в квазіізольованих умовах $i$ 
дозволяють створювати та керовано змінювати необхідні співвідношення температур між випарником, підкладкою, стінками та іншими конструкційними елементами. Показано, щзо просторовий розподіл температури у наведених конструкціях забезпечує випаровування (сублімацію) вихідного матеріалу, відбивання парів від нагрітих стінок, інтенсивну обмінну взаємодію між газовою фазою та поверхням конденсації і переважаючу конденсацію на поверхні підкладки, шуо сприяє дифузійному механізмові перенесення речовини і термодинамічно врівноваженому прочесу росту плівки. Показано, шчо для всіх модифікачій в більшій чи меншій мірі виконуються умови ізольованості локалізованого об' 'му та рівноважності процесу конденсації за рахунок створення необхідного температурного традієнту. Разом із тим, проблематичним є використання таких конструкиій для серійного виробництва через їхню складність і технологічні особливості. Тому метод термічного напилення тонких плівок в квазізамкненому об'ємі найчастіше використовують при виготовленні епітаксіальних монокристалічних шарів для наукових досліджень та експериментальних розробок, а для промислових виробництв дуже ефективними є розробки методів отримання тонких плівок, які поєднують в собі, з одного боку, універсальність термічного напилення у відкритому вакуумі, а з іншого - дозволяють наблизити процеси випаровування (сублімачії) - конденсацї до термодинамічної рівноваги, наприклад, різні варіанти “гарячих стінок”. Зазначено, ццо проаналізовані способи чи їхні модифікації є таким необхідним сьогодні засобом створення тонкоплівкових напівпровідникових структур із наперед заданими властивостями.

Ключові слова: тонкі плівки, напівпровідники, технологічні методи отримання, конденсація у вакуумі, термічне напилення, квазізамкнений об' $є м$.

\section{Introduction}

In the first part of this review (Aksimentyeva et al., 2018), a brief description of the methods to obtain thin films of inorganic semiconductors, in particular, the method of thermal spraying in an open vacuum, were given. This method, in comparison with others, has a number of significant advantages, such as high purity of synthesis, a wide range of variations in technological obtaining parameters, the possibility of industrial use, etc. However, the general disadvantages of many varieties and modifications of the indicated method are the nonequilibrium conditions of the film's growth, the dependence of the chemical composition of condensates on the rate of spraying, the deviation of the composition of films from stoichiometry. These disadvantages are caused by a significant difference in the temperature of the evaporation or sublimation and of the condensation surface, as well as of the saturated vapour pressure of the individual constituents of two or more component semiconductor compounds. Known modifications of thermo-vacuum deposition partially eliminate these shortcomings, but they do not allow to get rid of the fundamental and serious defects of all methods of sputtering these materials in an open vacuum - a significant unevenness of the condensation process, often with multiple over-saturation at the growth limit and no exchange interaction of the condensed and vapor phase due to the large (twice and in times more) the difference between the temperature of the evaporator and the surface of condensation, and the differences in the pressure of the saturated vapor of the individual components.

The indicated factors lead to the absence of thermodynamic equilibrium, or a controlled deviation from it in the region of growth of the film, which ultimately results in uncontrolled changes in physical properties and low reproducibility of the results for sensitive to minor changes in the chemical composition and crystalline structure of the semiconductor materials. In addition, when thermal sputtering in an open vacuum, the directional growth of condensates is due to, as a rule, straight-line motion in the vacuum of particles from the evaporator to the substrate, and the absence of their influential interaction in the molecular beam, which leads to the emergence of the growth texture.

These circumstances stimulated the search for methods of vacuum condensation in equilibrium or nearconditions, and an effective solution to these problems is the application of films in a quasi-closed volume.

\section{Application of semiconductor films in a quasi-closed volume}

The spraying in a quasi-closed volume is conceptually close to the crystallization method from the equilibrium vapor phase (or the method of the dispensed ampoule), in which the starting material and the substrate are placed at the opposite ends of the dispersed quartz ampoule and, with the help of the corresponding temperature gradient, optimal supersaturation at the interface of the steam vapour condensate is created.

The term "quasi-closed" or "closed" volume denotes special collapsible devices (containers, chambers) that are located in vacuum during the process, contain the source material and the substrate in quasi-isolated conditions, and allow to create and manage changes in the required temperature ratios between evaporator, lining, walls and all of its other structural elements (Bubnov et al., 1975; Kalinkin et al., 1978; Chopra \& Das, 1983; Kolesnikov, 1985; Frey \& Khan, 2015; Aksimentyeva et al., 2018). In such a localized volume after the start of sputtering only a negligible part of the sublimated pair leaves the quasiclosed cell through the slits of collapsible elements, which practically does not affect the total vapour pressure and provides a thermodynamic equilibrium. The most complete and systematic description of the principles of applying thin films in the quasi-closed volume, the processes of evaporation and condensation, the mechanisms of mass transfer, patterns of formation of the structure and composition of condensates, in this case, is made by Yu.Z. Bubnov and co-authors (Bubnov et al., 1975).

The design chamber for spraying in a quasi closed loop has the form of an empty cylinder made of graphite, quartz, mullite, alund, or other heat-resistant material, in the lower part of which is an evaporator, and the upper one is a condensation substrate. An important element is a reflective (thermal) screen that eliminates the direct hit of sublimated molecules and macroparticles on the substrate and causes the processes of their intense collisions between themselves and with the walls and other parts of the chamber, which helps to reduce the lengths of free run 
of the molecules and excludes the directional transfer of material to the substrate, that eliminates the problem of texture of condensates.

The determination factors for the application in the quasi-closed volume are the thermal modes and the temperature correlation between the individual elements of the chamber during the spraying process. For this purpose, the lower and upper parts of the chamber (evaporator and lining holder respectively) are equipped with special autonomous heaters. If necessary, the camera walls and the reflecting screen are additionally heated. The spatial temperature distribution in the quasi-closed volume should provide the evaporation (sublimation) of the source material, the reflection of vapor from the heated walls, the intense exchange interaction between the gas phase and all possible condensation surfaces and, finally, the predominant condensation on the substrate surface, thereby contributing to the diffusion transfer mechanism substances, gasdynamic flow (in contrast to the directed molecular beam at thermal evaporation in an open vacuum), that is, thermodynamically balanced film growth process. For this temperature of the substrate is set to several tens of degrees (depending on the type of material and deposition conditions) lower than the temperature of the other parts of the chamber, which results in condensation of homogeneous multicomponent mixture of vapors which is in equilibrium state.

Depending on the tasks and the expected results, various construction types of the thermal spraying method in a quasi closed volume are used, such as a closed crucible with double perforated disks, (Kalinkin et al., 1978, Fig. 1, a), a stationary container with a thermal screen (Krasulin \& Vanyukov, 1970, Fig. 1, b), onesection and two-sections "hot wall" (Aksimentyeva et al., 2018, Fig. 1, c), camera with high-temperature tubular heater (Bubnov et al., 1975, Fig. 1, d), reactor combining evaporation chamber and substrate (Kalinkin et al., 1978, Fig. 1,e), camera with cassette placement of substrates (Bubnov et al., 1975, Fig. 1, f), collapsible chamber for replacement of substrates, a combined conic chamber, a quartz bowl with an autonomous source for doping (Kiriashkina et al., 1979, Fig. 2, a), graphite chamber with chemically active diaphragm (Bubnov et al., 1975, Fig. 2, $b$ ), device for the independent evaporation of two substances (Kalinkin et al., 1978, on Fig. 2, c, $d$ the assembly is pictured before and during the synthesis), double quasi-closed volume and others.
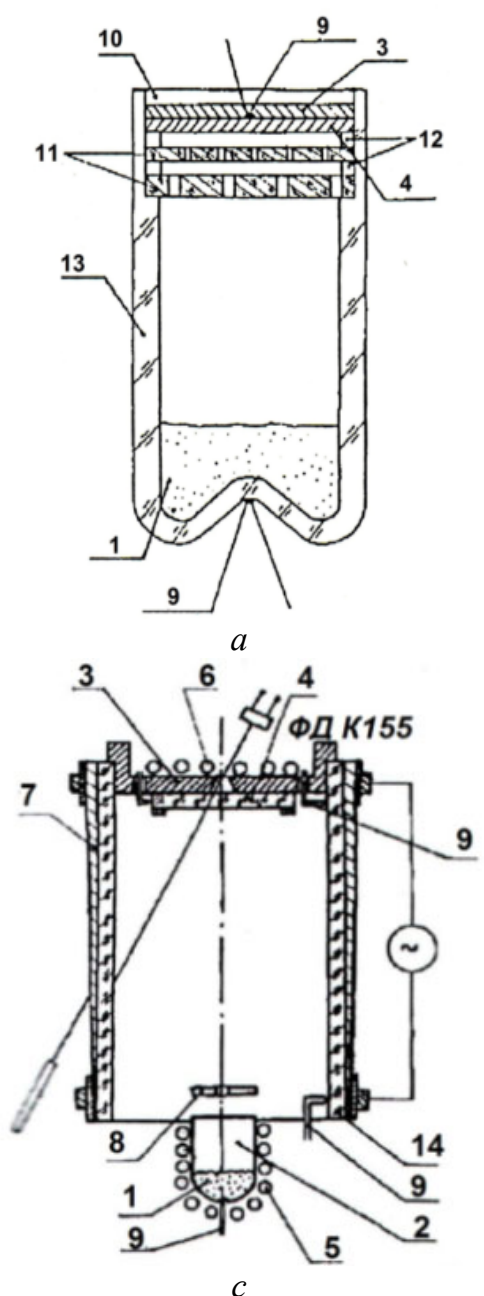

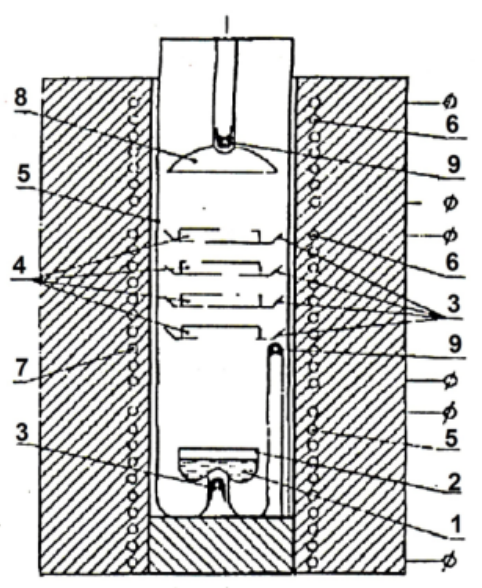

$b$

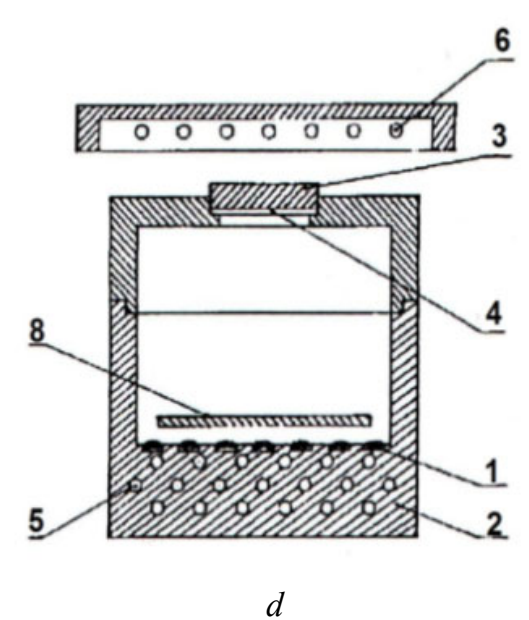




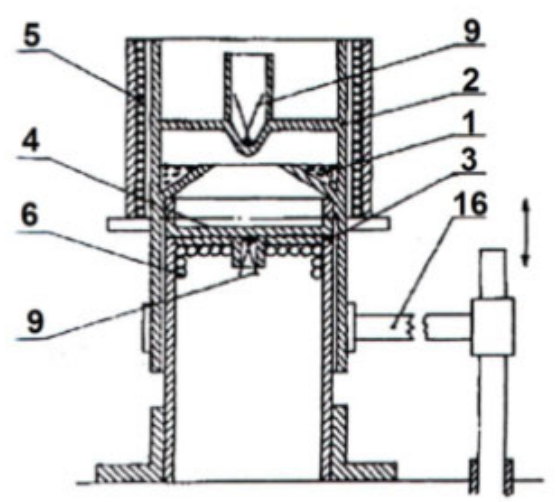

$e$

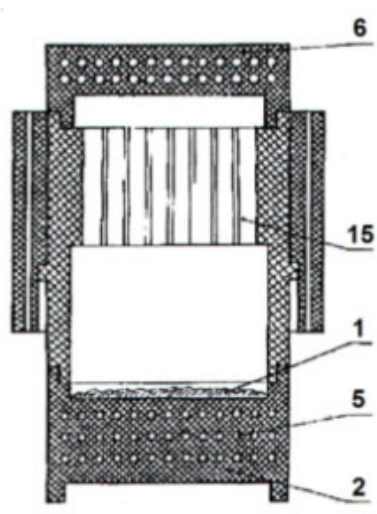

$f$

Fig. 1. Constructions of devices for thermal spraying of semiconductor thin films in a quasi-closed volume with sublimation of one substance: 1 - source material, 2 - evaporator, 3 - apposition holder, 4 - apposition, 5 - evaporator heater, 6 - substrate heater, 7 - wall heater, 8 - reflecting screen, 9 - thermocouple, 10 - quartz disk, 11 - disk with

holes, 12 - quartz rings, 13 - quartz reactor, 14 - quartz cylinder, 15 - diaphragm with holes, 16 - manipulator

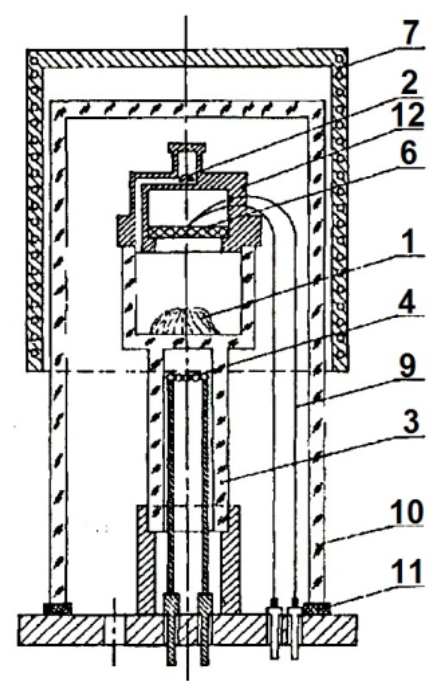

$a$

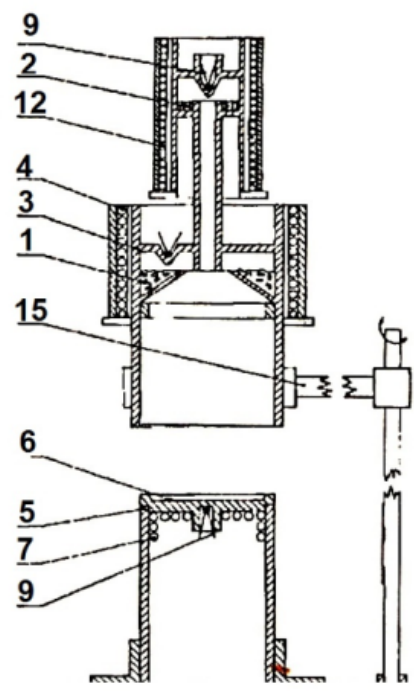

$c$

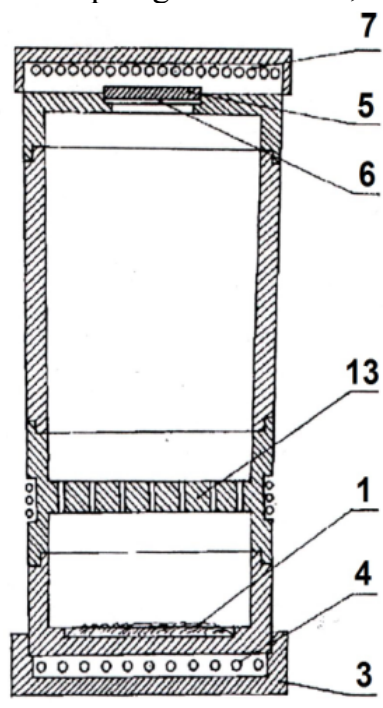

$b$

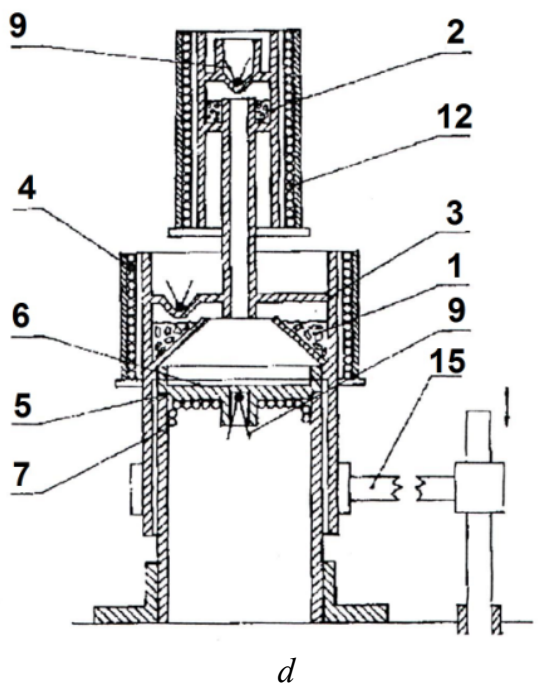

Fig. 2. Constructions of devices for thermal application of semiconductor thin films in a quasi-closed volume with evaporation of two substances: 1 - source material, 2 -dopant, 3 - evaporator, 4 - evaporator heater, 5 -apposition holder, 6 - apposition, 7 - apposition heater, 8 - heat screen, 9 - thermocouple, 10 - quartz cap, 11 - denser, 12 - semi-autonomous source for dopant, 13 - diaphragm with heater, 14 - quartz tube, 15 - manipulator 
In Fig. 1 and Fig. 2, the most characteristic types of constructions (designs) of the method of thermal spraying in a quasi-closed volume are shown. As can be seen, for all modifications to a greater or lesser extent, the conditions for the isolation of the localized volume and the equilibrium of the condensation process are fulfilled by creating the necessary temperature gradient. At the same time, it would be problematic, and often impossible, to use such designs for large-scale production due to their complexity and technological features. Therefore, the method of thermal spraying of thin films in the quasiclosed volume is most often used in the production of epitaxial monocrystalline layers for scientific research and experimental development. Instead, for industrial production, it is very effective to develop methods for obtaining thin films that combine, on the one hand, the universality of thermal spraying in open vacuum, and on the other - allows to bring the processes of evaporation (sublimation) closer - condensation to the thermodynamic equilibrium, for example, different variants of "hot walls".

\section{Conclusions}

The features of thermal application of semiconducting thin films in a quasi-closed volume are described. The disadvantages of thermal filtration of thin films in an open vacuum for multicomponent semiconductor compounds are indicated. The constructions of vacuum-vapour vacuum chamber compartments in a quasi-closed volume containing the raw material and substrate in quasi-isolated conditions with the possibility to create and manage the necessary temperature corrections between the evaporator, lining, walls and other structural elements are presented. It is shown that the spatial temperature distribution in the mentioned constructs provides the evaporation (sublimation) of the source material, the reflection of vapor from the heated walls, the intensive exchange interaction between the gas phase and the condensation surfaces and the prevailing condensation on the substrate surface, which contributes to the diffusion mechanism of the transfer of matter and the thermodynamically balanced growth process films.

This work was supported by the project of Ministry of Education and Science of Ukraine "Development of organo-inorganic thin film reversible structures for multifunctional gas sensors" (state registration number 0118u003496).

\section{References}

Aksimentyeva, O., Tsizh, B., \& Chokhan', M. (2018). Sensory kontrolyu gazovyh seredovyshch u harchoviy promyslovosti ta dovkilli: monografiya. Lviv, Piramida (in Ukrainian).

Bubnov, Yu.Z., Lurie, M.S., Staros, F.G., \& Filaretov, A.G. (1975). Vakuumnoye naniesieniye plyonok v kvazizamknutom obyomie. Moskva, Sovietskoye radio (in Russian).

Chopra, K.L., \& Das, S.R. (1983). Thin Film Solar Cells. New York, Plenum Press. https://www.springer.com/ gp/book/9780306411410.

Fizychni osnovy elektronnoyi tehniky. Za red. Z. Yu. Hotry (2004). Lviv, Beskyd Bit (in Ukrainian).

Frey, H., \& Khan, H.R. (2015). Handbook of Thin Film Technology, Springer. https://www.springer.com/us/ book/9783642054297.

Handbook of Deposition Technologies for Films and Coatings. Edited by Rointan F. Bunshah. (1994). New Jersey, Noyes Publication. https://www.elsevier.com/ books/handbook-of-deposition-technologies-for-filmsand-coatings/bunshah/978-0-8155-1337-7.

Handbook of Thin Film Deposition Processes and Techniques. Edited by Krishna Seshan. (2002). New York, Noyes Publication. William Andrew Publication. https://www.elsevier.com/books/handbook-of-thinfilm-deposition/seshan/978-1-4377-7873-1.

Kalinkin, I.P., Alieskovskiy, V.B., \& Simashkievich, A.V. (1978). Epitaksial'nyie plionki soyedinieniy $\mathrm{A}^{\mathrm{II}} \mathrm{B}^{\mathrm{VI}}$. Lieningrad, Izdatielstvo Lieningradskogo univiersitieta. https://meshok.net/?related $=\% \mathrm{D} 0 \% 9 \mathrm{~A} \%$ D0\%B0\%D9+\%D0\%90+II+B+VI (in Russian).

Kalynushkin, Ye.P., Fedorkova, N.M., \& Synytsina, Yu.P. (2009). Tonkoplivkovi materialy ta tehnologiyi yih oderzhannia. Dnipropetrovs'k, NMetAU (in Ukrainian).

Kiriashkina, Z.I., Rokah, A.G., Kats, N.B., Malkov, V.P., Novikova, E.A., \& Tsukerman, N.M. (1979). Fotoprovodiashchiye plyonki (tipa CdS). Saratov, Izdatielstvo Saratovskogo univiersitieta (in Russian).

Koliesnikov, V.P. (1985). Mietody poluchieniya tonkih fotochuvstvitiel'nyh plionok CdS. Tonkiye plionki v optoelektronikie. Tbilisi, Mitsniyerieba https://nmetau.edu.ua/file/navchalniy_posibnik_tonko plivkovi_materiali.pdf (in Russian).

Krasulin, G.A., \& Vanyukov, A.V. (1970). Osazhdieniye mohokristallicheskih plyonok sulfida kadmiya V kvaziravnovyesnyh usloviyah. Izv. AN SSSR. Ser. Neorgan. mater., 6(1), 122-124. (in Russian).

Shahinian, L.R. (2017). The Mechanisms of Formation of Thin Films and Coatings Deposited by Physical Vapor Deposition Technology. Kyiv, Akademperiodyka. http://akademperiodyka.org.ua/en/books/the_mechanis ms_of_formation_of_thin_films_and_coatings_deposi ted_by_physical_vapor_deposition_technology.

Sharma, B. L., \& Purohit R. K. (19̄̄4). Semiconductor heterojunctions. New York, Pergamon Press. https:/www.worldcat.org/title/semiconductorheterojunctions/oclc/742483550.

Tsizh, B., \& Dziamski, Z. (2019). Technological Methods of Forming Thin Semiconductor Layers. Part 1. Scientific Messenger LNUVMB. Series: Food Technologies. 21, 91, 20-24. doi: 10.32718/nvlvet-f9104. 